Biotechnology

for Biofuels

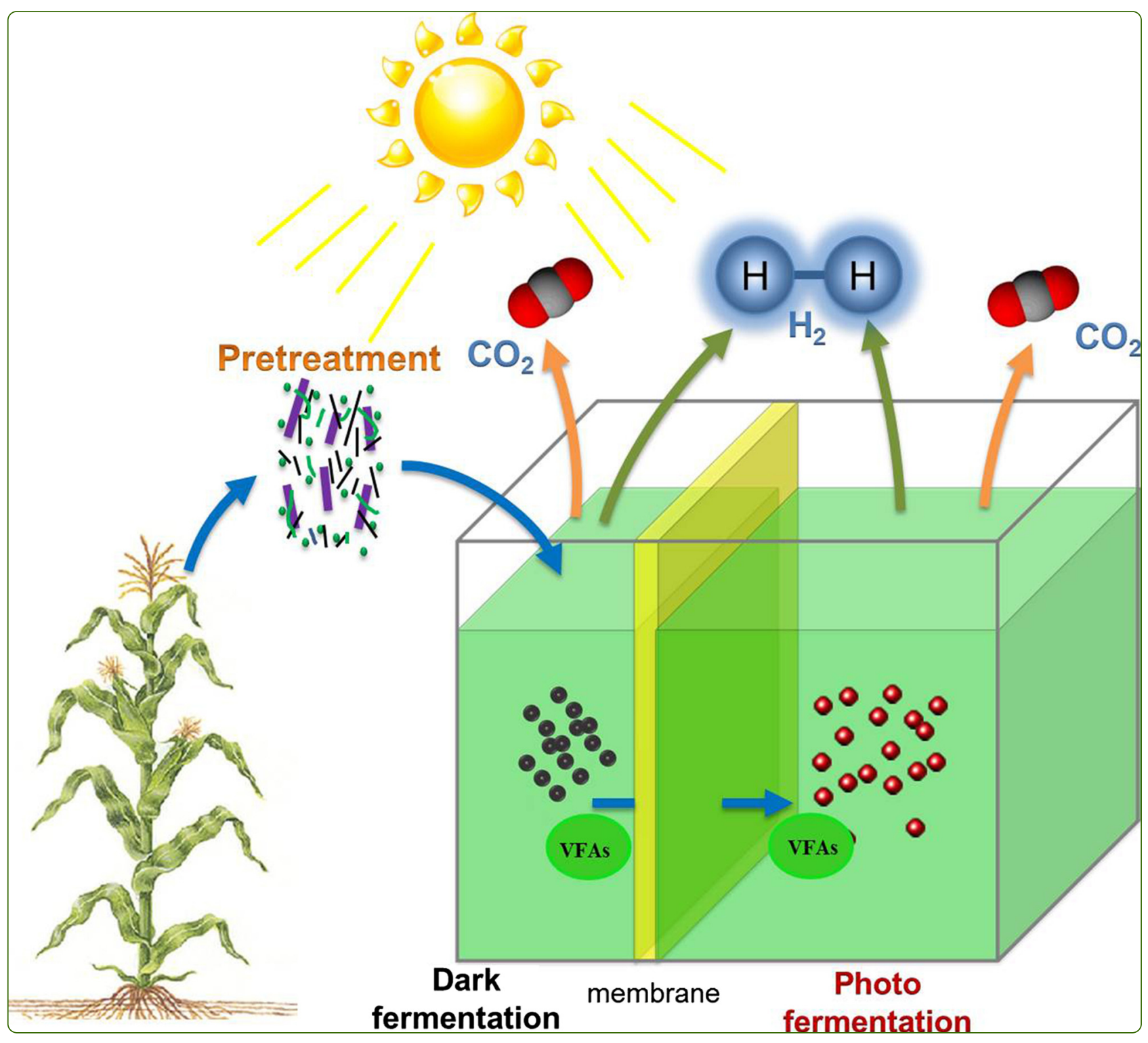

Simultaneous hydrogen and ethanol production from cascade utilization of mono-substrate in integrated dark and photo-fermentative reactor Liu et al. 


\title{
Simultaneous hydrogen and ethanol production from cascade utilization of mono-substrate in integrated dark and photo-fermentative reactor
}

Bing-Feng Liu', Guo-Jun Xie ${ }^{1,2^{*}}$, Rui-Qing Wang ${ }^{1}$, De-Feng Xing ${ }^{1}$, Jie Ding ${ }^{1}$, Xu Zhou ${ }^{2}$, Hong-Yu Ren ${ }^{1}$, Chao $\mathrm{Ma}^{1}$ and Nan-Qi Ren ${ }^{1 *}$

\begin{abstract}
Background: Integrating hydrogen-producing bacteria with complementary capabilities, dark-fermentative bacteria (DFB) and photo-fermentative bacteria (PFB), is a promising way to completely recover bioenergy from waste biomass. However, the current coupled models always suffer from complicated pretreatment of the effluent from dark-fermentation or imbalance between dark and photo-fermentation, respectively. In this work, an integrated dark and photo-fermentative reactor (IDPFR) was developed to completely convert an organic substrate into bioenergy.

Results: In the IDPFR, Ethanoligenens harbinese B49 and Rhodopseudomonas faecalis RLD-53 were separated by a membrane into dark and photo chambers, while the acetate produced by E. harbinese B49 in the dark chamber could freely pass through the membrane into the photo chamber and serve as a carbon source for $R$. faecalis RLD-53. The hydrogen yield increased with increasing working volume of the photo chamber, and reached $3.38 \mathrm{~mol} \mathrm{H} / \mathrm{mol}$ glucose at the dark-to-photo chamber ratio of 1:4. Hydrogen production by the IDPFR was also significantly affected by phosphate buffer concentration, glucose concentration, and ratio of dark-photo bacteria. The maximum hydrogen yield ( $4.96 \mathrm{~mol} \mathrm{H} / \mathrm{mol}$ glucose) was obtained at a phosphate buffer concentration of $20 \mathrm{mmol} / \mathrm{L}$, a glucose concentration of $8 \mathrm{~g} / \mathrm{L}$, and a ratio of dark to photo bacteria of 1:20. As the glucose and acetate were used up by E. harbinese B49 and R. faecalis RLD-53, ethanol produced by E. harbinese B49 was the sole end-product in the effluent from the IDPFR, and the ethanol concentration was $36.53 \mathrm{mmol} / \mathrm{L}$ with an ethanol yield of $0.82 \mathrm{~mol}$ ethanol/mol glucose.
\end{abstract}

Conclusions: The results indicated that the IDPFR not only circumvented complex pretreatments on the effluent in the two-stage process, but also overcame the imbalance of growth and metabolic rate between DFB and PFB in the co-culture process, and effectively enhanced cooperation between E. harbinense B49 and R. faecalis RLD-53. Moreover, simultaneous hydrogen and ethanol production were achieved by coupling E. harbinese B49 and R. faecalis RLD-53 in the IDPFR. According to stoichiometry, the hydrogen and ethanol production efficiencies were $82.67 \%$ and $82.19 \%$, respectively. Therefore, IDPFR was an effective strategy for coupling DFB and PFB to fulfill efficient energy recovery from waste biomass.

Keywords: Hydrogen production, Ethanol production, Dark-fermentation, Photo-fermentation, Integrated dark and photo-fermentative reactor, Kinetics, Membrane

\footnotetext{
*Correspondence: g.xie@uq.edu.au; rnq@hit.edu.cn

'State Key Laboratory of Urban Water Resource and Environment, Harbin Institute of Technology, Harbin 150090, China

${ }^{2}$ Advanced Water Management Centre, The University of Queensland, St. Lucia QLD 4072, Australia
}

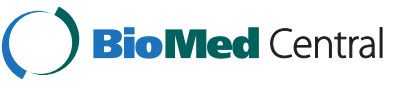

(c) 2015 Liu et al.; licensee BioMed Central. This is an Open Access article distributed under the terms of the Creative Commons Attribution License (http://creativecommons.org/licenses/by/4.0), which permits unrestricted use, distribution, and reproduction in any medium, provided the original work is properly credited. The Creative Commons Public Domain Dedication waiver (http://creativecommons.org/publicdomain/zero/1.0/) applies to the data made available in this article, unless otherwise stated. 


\section{Background}

Energy shortages and environmental pollution resulting from fossil fuels have been gaining global concern and driving worldwide use of renewable energy to achieve a more secure, reliable, and sustainable energy system $[1,2]$. Hydrogen has been attracting great interest as a clean, renewable, and effective energy carrier that could minimize our dependence on fossil fuel-derived energy and therefore enhance the global economy and reduce environmental pollution. Nevertheless, nearly $96 \%$ of hydrogen is produced through thermochemical processes using fossil fuel as an energy source [3], which is energy intensive, unsustainable, and not environmentally friendly. In contrast, microbial hydrogen recovery from renewable sources like organic wastes and sunlight is mostly operated at ambient temperatures and pressures [4]. Therefore, biological hydrogen production is considered an important step to a sustainable world power supply with the potential to replace fossil fuels [5].

Photo and dark-fermentation are the main pathways for biological hydrogen production. Photo-fermentative bacteria (PFB) could convert $100 \%$ of organic wastes into hydrogen and carbon dioxide by harvesting energy from sunlight. However, most PFB live on short-chain fatty acids, such as acetic, propionic, and butyric acids [6-8] and can hardly use glucose and other macromolecular organics. This greatly limits hydrogen production from complex organic wastes through photo-fermentation. Conversely, dark-fermentative bacteria (DFB) produce hydrogen from various complex organic wastes at high rates via butyric acid-type, propionic acid-type, or ethanol-type fermentation [9], but the hydrogen yield is limited by end products such as acetic, propionic, and butyric acids. As a result, the maximum hydrogen yield for dark-fermentation is $4 \mathrm{~mol} \mathrm{H}_{2} / \mathrm{mol}$ hexose, which is far from the theoretical maximum value of $12 \mathrm{~mol} \mathrm{H}_{2} / \mathrm{mol}$ hexose [5,10]. However, the short-chain fatty acids produced by DFB provide a carbon source for cell growth and electron donors for hydrogen production by PFB. Therefore, combining DFB and PFB with complementary capabilities is a promising way to completely convert complex organic wastes into hydrogen.

Currently, the combination of dark and photofermentation is mainly achieved through a two-stage or co-culture process. In the two-stage process, the effluent from dark-fermentation serves as the carbon source for photo-fermentation [11]. High hydrogen yields can be obtained by the two-stage process, because DFB and PFB work separately under their respective optimal conditions. However, the effluent from dark-fermentation contains DFB, high concentration of short-chain fatty acids leading to low $\mathrm{pH}$ values, and sometimes ammonium, which significantly inhibits the nitrogenase activity of PFB. As a result, the effluents have to be centrifuged to remove DFB and any colloidal materials that may interfere with light penetration [12], their $\mathrm{pH}$ must be adjusted by additional chemical agents, then they must be diluted with distilled water, the ammonium removed [13-17], and they may even have to be re-flushed with argon and re-sterilized before reaching the optimum conditions for photo-fermentation. These complex pretreatments on the effluent from darkfermentation not only greatly increase the operation costs, but also make it hard for continuous operation, especially in large-scale applications.

In the co-culture process, DFB and PFB are mixed and cultured in one system. Short-chain fatty acids produced by DFB are converted in situ into hydrogen by PFB without complex pretreatments. This not only alleviates the end-product inhibition on dark fermentation [18], but also prevents the $\mathrm{pH}$ drop resulting from short-chain fatty acid accumulation. However, cell growth rates of DFB are 0.15$1.12 \mathrm{~h}^{-1}$ [19-21], while cell growth rates of PFB are only $0.025-0.074 \mathrm{~h}^{-1}$ [22-25]. DFB will eventually dominate the co-culture system, in spite of increased inoculation with PFB. Moreover, the imbalance of organic acid production and consumption rates between DFB and PFB could lead to accumulation of organic acids and decrease of $\mathrm{pH}$. Compared with DFB, PFB are more sensitive to $\mathrm{pH}$ change; their optimum $\mathrm{pH}$ is from 6.5 to 7.5. A large amount of phosphates are required in the co-culture system to provide sufficient buffer capacity, which greatly increases the operation costs. In addition, PFB suffer a light shading effect from DFB in the co-culture system, which could decrease the light conversion efficiency. As a result, it is difficult to set up a stable co-culture process.

The objective of this study was to develop a novel hydrogen production mode by coupling dark and photofermentation to take full advantage of the complementary capabilities of DFB and PFB and reduce operating costs. The kinetic characteristics of growth and hydrogen production of the DFB, Ethanoligenens harbinese B49, and the PFB, Rhodopseudomonas faecalis RLD-53, were determined. Based on the kinetics of DFB and PFB, we designed a novel integrated dark and photo-fermentative reactor (IDPFR). The hydrogen production of this novel reactor was also investigated under different operating conditions.

\section{Results and discussion}

\section{Kinetics of dark and photo-fermentative bacteria}

The kinetics of cell growth, hydrogen production, acetic acid production, and consumption of $E$. harbinese B49 and $R$. faecalis RLD-53 were investigated under their own optimal conditions [26,27] with a logistic model, modified Gompertz equation, and modified Richards model, respectively (Figure 1), and the main kinetic parameters are summarized in Table 1. At a glucose concentration of $10 \mathrm{~g} / \mathrm{L}$, the maximum hydrogen production rate $\left(R_{H_{2}}\right)$ of E. harbinense $\mathrm{B} 49$ was $163.98 \mathrm{ml} / \mathrm{L} / \mathrm{h}$, which was more 

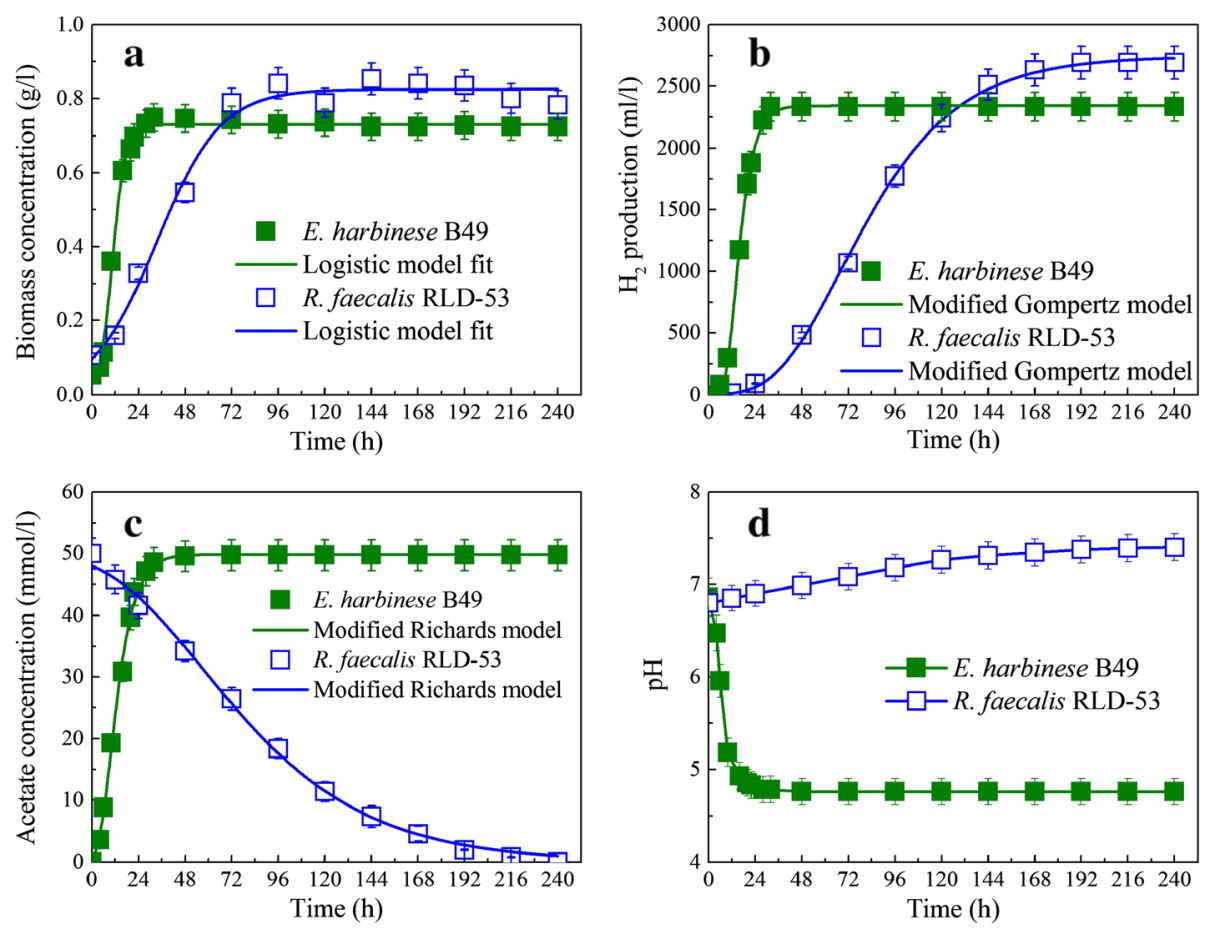

Figure 1 Kinetic characterizations of dark and photo-fermentative bacteria. (a) Cell growth kinetics; (b) $\mathrm{H}_{2}$ production kinetics; (c) acetate production and consumption kinetics; (d) pH change during fermentation.

than five times that of $R$. faecalis RLD-53. $49.84 \mathrm{mmol} / \mathrm{L}$ of acetate was produced by $E$. harbinense $\mathrm{B} 49$ with a maximum production rate $\left(R_{p H A c}\right)$ of $2.73 \mathrm{mmol} / \mathrm{L} / \mathrm{h}$, while the maximum acetate degradation rate $\left(R_{d H A c}\right)$ by $R$. faecalis RLD-53 was only $0.38 \mathrm{mmol} / \mathrm{L} / \mathrm{h}$ at an acetate concentration of $50 \mathrm{mmol} / \mathrm{L}$ (Table 1). The results showed that the maximum acetate production rate by $E$. harbinense $\mathrm{B} 49$ was about seven times the degradation rate by $R$. faecalis RLD-53. In addition, the specific growth rate $\left(k_{c}\right)$ of $E$. harbinense $\mathrm{B} 49$ was $0.31 \mathrm{~h}^{-1}$, which indicated that $E$. harbinense B49 grows more slowly than Clostridium butyricum CGS5 with a specific growth rate of $0.77 \mathrm{~h}^{-1}$ [20] and Enterobacter cloacae IIT-BT 08 with a specific growth rate of $1.12 \mathrm{~h}^{-1}$ [21]. The specific growth rate $\left(k_{c}\right)$ of $R$. faecalis RLD-53 was $0.06 \mathrm{~h}^{-1}$, which was much faster

Table 1 The kinetic parameters of dark and photofermentative bacteria

\begin{tabular}{lll}
\hline Kinetic parameters & E. harbinense B49 & R. faecalis RLD-53 \\
\hline$X_{\max }(\mathrm{g} / \mathrm{L})$ & 0.73 & 0.82 \\
$k_{C}\left(\mathrm{~h}^{-1}\right)$ & 0.31 & 0.06 \\
$H_{\max }(\mathrm{ml} / \mathrm{L})$ & 2342.18 & 2737.45 \\
$R_{H_{2}}(\mathrm{ml} / \mathrm{L} / \mathrm{h})$ & 163.98 & 30.47 \\
$\lambda_{H_{2}}(\mathrm{~h})$ & 8.66 & 35.54 \\
$R_{p H A c}$ and $R_{d H A c}(\mathrm{mmol} / \mathrm{L} / \mathrm{h})$ & 2.73 & 0.39 \\
$\mathrm{pH}$ & $6.80-4.75$ & $6.80-7.42$ \\
\hline
\end{tabular}

than Rhodobacter capsulatus DSM 1710 with a specific growth rate of $0.025 \mathrm{~h}^{-1}$ [22], but slightly slower than Rhodopseudomonas palustris with a specific growth rate of $0.074 \mathrm{~h}^{-1}$ [24]. The results also showed that the specific growth rate of $E$. harbinense $\mathrm{B} 49$ was about five times faster than that of R. faecalis RLD-53 (Table 1). Therefore, the imbalance of metabolic and cell growth rate between the two types of bacteria could exacerbate the accumulation of acetic acid, which would decrease the $\mathrm{pH}$ and subsequently inhibit $R$. faecalis RLD-53. In the IDPFR, a membrane with pore size $0.22 \mu \mathrm{m}$ was used to divide the reactor into two separate reaction chambers. In the dark chamber, complex waste biomass was converted by $E$. harbinense B49 into hydrogen, carbon dioxide, ethanol, and acetate. Acetate could diffuse through the membrane into the photo chamber. In the photo chamber, acetate from the dark chamber was utilized by $R$. faecalis RLD-53 to produce hydrogen and carbon dioxide. By increasing the working volume of the photo chamber, more $R$. faecalis RLD-53 could couple with $E$. harbinense B49, and the organic acids produced by $E$. harbinense B49 could be expected to be consumed completely by $R$. faecalis RLD-53 without accumulation.

$\mathrm{H}_{2}$ production by IDPFR at different working volume ratios In the IDPFR, the working volume ratio of the dark and photo chambers was investigated to overcome the imbalance of cell growth and metabolic rate between $E$. 
harbinense B49 and R. faecalis RLD-53. The working volume of the dark chamber was a constant value of $40 \mathrm{ml}$, while the working volume of the photo chamber was $80,120,160$, and $200 \mathrm{ml}$, corresponding to a working volume ratio at 1:2, 1:3, 1:4, and 1:5. In this test, the phosphate buffer concentration was $10 \mathrm{mmol} / \mathrm{L}$, and the initial glucose concentration was $10 \mathrm{~g} / \mathrm{L}$.

The hydrogen production volume increased with darkto-photo chamber ratio from $1: 2$ to $1: 4$, and decreased with a ratio from 1:4 to 1:5 (Figure 2). At a working volume ratio of $1: 2$, hydrogen production by the dark chamber was $1,791.67 \mathrm{ml} / \mathrm{L}$, while hydrogen production by the photo chamber was only $1,138.97 \mathrm{ml} / \mathrm{L}$. The total hydrogen production was $2,930.63 \mathrm{ml} / \mathrm{L}$ with a hydrogen yield of $2.35 \mathrm{~mol} \mathrm{H}_{2} / \mathrm{mol}$ glucose. With an increase of photo chamber working volume, more $R$. faecalis RLD-53 could use the end product from $E$. harbinense B49 for hydrogen production, while $E$. harbinense $\mathrm{B} 49$ was restricted in the small dark chamber. Acetic acid produced by $E$. harbinense B49 was not accumulated but converted into hydrogen by $R$. faecalis RLD-53. Consequently, hydrogen production by photo chamber increased significantly. At a working volume ratio of 1:4, hydrogen production by the dark and photo chambers reached maximum simultaneously at $1,991.67$ and $2,225.15 \mathrm{ml} / \mathrm{L}$, with a hydrogen yield of $3.38 \mathrm{~mol} \mathrm{H}_{2} / \mathrm{mol}$ glucose. However, with a further decrease of the working volume ratio to $1: 5$, total hydrogen production decreased sharply to $3,269.29 \mathrm{ml} / \mathrm{L}$ with a hydrogen yield of $2.63 \mathrm{~mol} \mathrm{H}_{2} / \mathrm{mol}$ glucose.

The glucose concentration in the dark chamber gradually decreased due to consumption by $E$. harbinense B49. The glucose diffused spontaneously from the photo to the dark chamber for further consumption by $E$. harbinense B49. Consequently, the glucose concentration in the photo chamber was slightly higher than that in the dark chamber, but glucose concentration in both chambers decreased following the same trend. Acetate diffused into the photo chamber through the membrane and was converted by RLD-53 into hydrogen and carbon dioxide. The acetate production rate by $\mathrm{B} 49$ was much faster than the consumption rate of $R$. faecalis RLD-53. Consequently, acetate accumulated in the reactor, and reached maximum

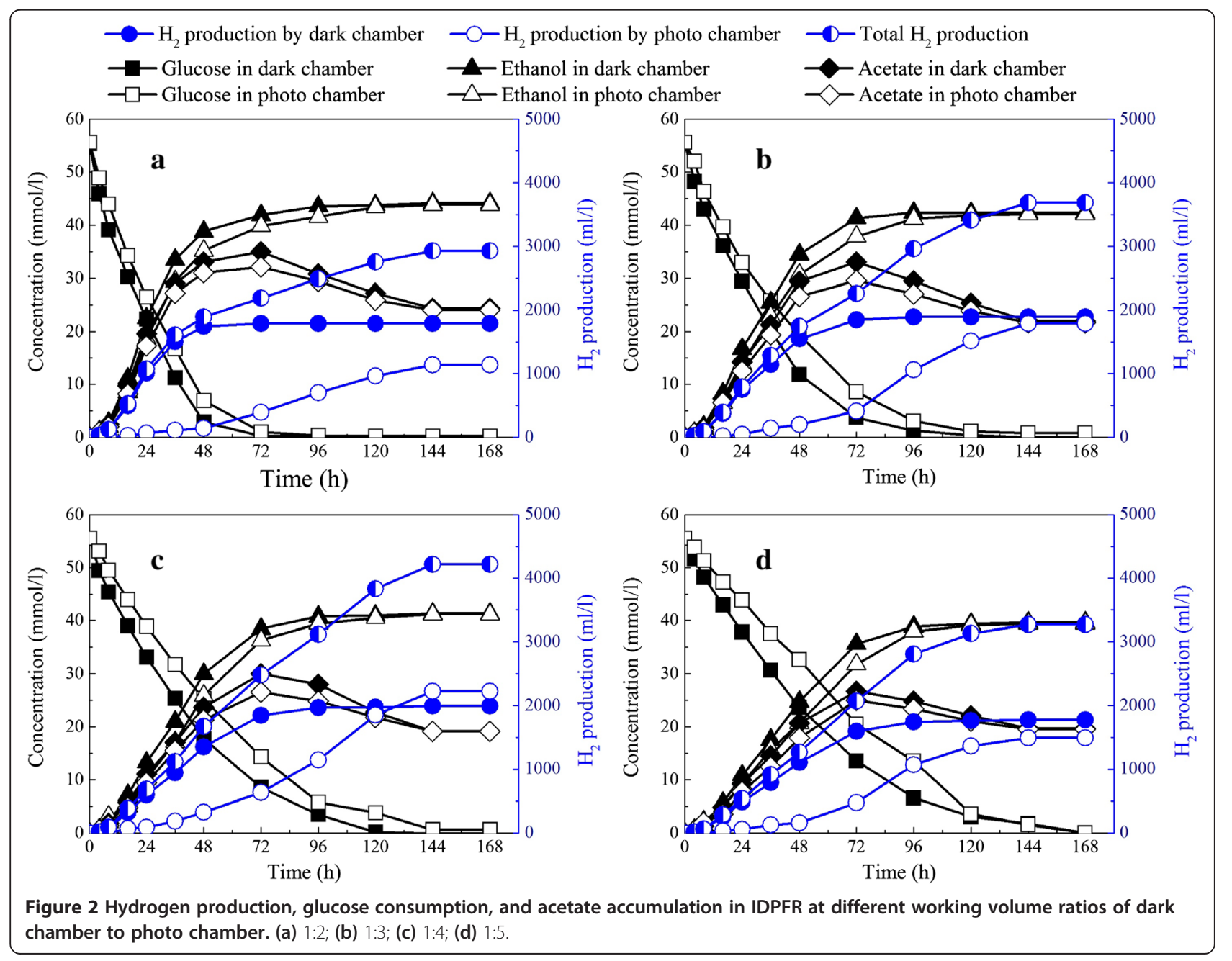


value at about $72 \mathrm{~h}$. The maximum accumulation of acetate decreased from $34.95 \mathrm{mmol} / \mathrm{L}$ to $26.72 \mathrm{mmol} / \mathrm{L}$ with the increase of photo chamber working volume. A previous study showed that acetate has been proved to have an inhibitory effect on hydrogen production by $E$. harbinese B49 [28]. In the IDPFR, acetate consumed by $R$. faecalis RLD-53 could alleviate the inhibition of acetate on hydrogen production and also facilitate a stable $\mathrm{pH}$ of the coupled system.

\section{Effect of phosphate concentration on $\mathrm{H}_{2}$ production by IDPFR}

In the IDPFR, phosphate not only serves as a phosphorus source for microbial growth, but also can buffer the $\mathrm{pH}$ change in the fermentation system. Hydrogen production by the IDPFR was investigated at different phosphate concentrations $(10,20$, and $30 \mathrm{mmol} / \mathrm{L})$. In this test, the working volume of the dark chamber was $40 \mathrm{ml}$, while the working volume of the photo chamber was $160 \mathrm{ml}$, corresponding to a total working volume of $200 \mathrm{ml}$.

As shown in Figure 3, at a phosphate concentration of $10 \mathrm{mmol} / \mathrm{L}$, the total hydrogen production was $4,199.14 \mathrm{ml} / \mathrm{L}$ and the hydrogen yield reached $3.37 \mathrm{~mol}$ $\mathrm{H}_{2} /$ mol glucose. When the phosphate concentration increased to $20 \mathrm{mmol} / \mathrm{L}$, the total hydrogen production was $4,766.90 \mathrm{ml} / \mathrm{L}$ and the hydrogen yield reached $3.83 \mathrm{~mol}$ $\mathrm{H}_{2} / \mathrm{mol}$ glucose. The result indicated that the increase of phosphate concentration from 10 to $20 \mathrm{mmol} / \mathrm{L}$ was conducive to hydrogen production by dark and photofermentation. However, with a further increase of phosphate concentration to $30 \mathrm{mmol} / \mathrm{L}$, hydrogen production by $R$. faecalis RLD-53 in the photo chamber decreased sharply to $1,893.93 \mathrm{ml} / \mathrm{L}$, and the hydrogen yield was only $3.18 \mathrm{~mol} \mathrm{H}_{2} / \mathrm{mol}$ glucose. The high concentration of phosphate also inhibited hydrogen production by $R$. faecalis RLD-53, and therefore decreased hydrogen production by the IDPFR. With an increase of phosphate concentration from $10 \mathrm{mmol} / \mathrm{L}$ to $20 \mathrm{mmol} / \mathrm{L}$, acetate concentration in the end product decreased from 17.03 to $13.04 \mathrm{mmol} / \mathrm{L}$. Consequently, the end $\mathrm{pH}$ of the IDPFR increased from 5.8 to 6.2 , which approximated the optimum $\mathrm{pH}$ (6.5-7.5) for $R$. faecalis RLD-53. However, when the phosphate concentration was further increased to $30 \mathrm{mmol} / \mathrm{L}$, the acetate concentration significantly increased to $20.78 \mathrm{mmol} / \mathrm{L}$, probably due to inhibition of cell growth and hydrogen production activities resulting from the high phosphate concentration. As a result, acetate accumulation increased and therefore the end $\mathrm{pH}$ decreased to 5.6, which is unfavorable for PFB. Therefore, the maximum hydrogen yield was obtained at a phosphate concentration of $20 \mathrm{mmol} / \mathrm{L}$.

In the co-culture system, the imbalance of acetate production by $E$. harbinense $\mathrm{B} 49$ and consumption by $R$. faecalis RLD-53 and the $\mathrm{pH}$-sensitive PFB necessitate a high buffer capacity of the coupled system by adding phosphate. Hydrogen production by co-culture of $E$. harbinense $\mathrm{B} 49$ and immobilized $R$. faecalis RLD-53 reached a maximum $2.78 \mathrm{~mol} \mathrm{H}_{2} / \mathrm{mol}$ glucose at a phosphate concentration of $50 \mathrm{mmol} / \mathrm{L}$ [29]. However, a life cycle inventory analysis of biological hydrogen production by coupling dark and photo-fermentation showed
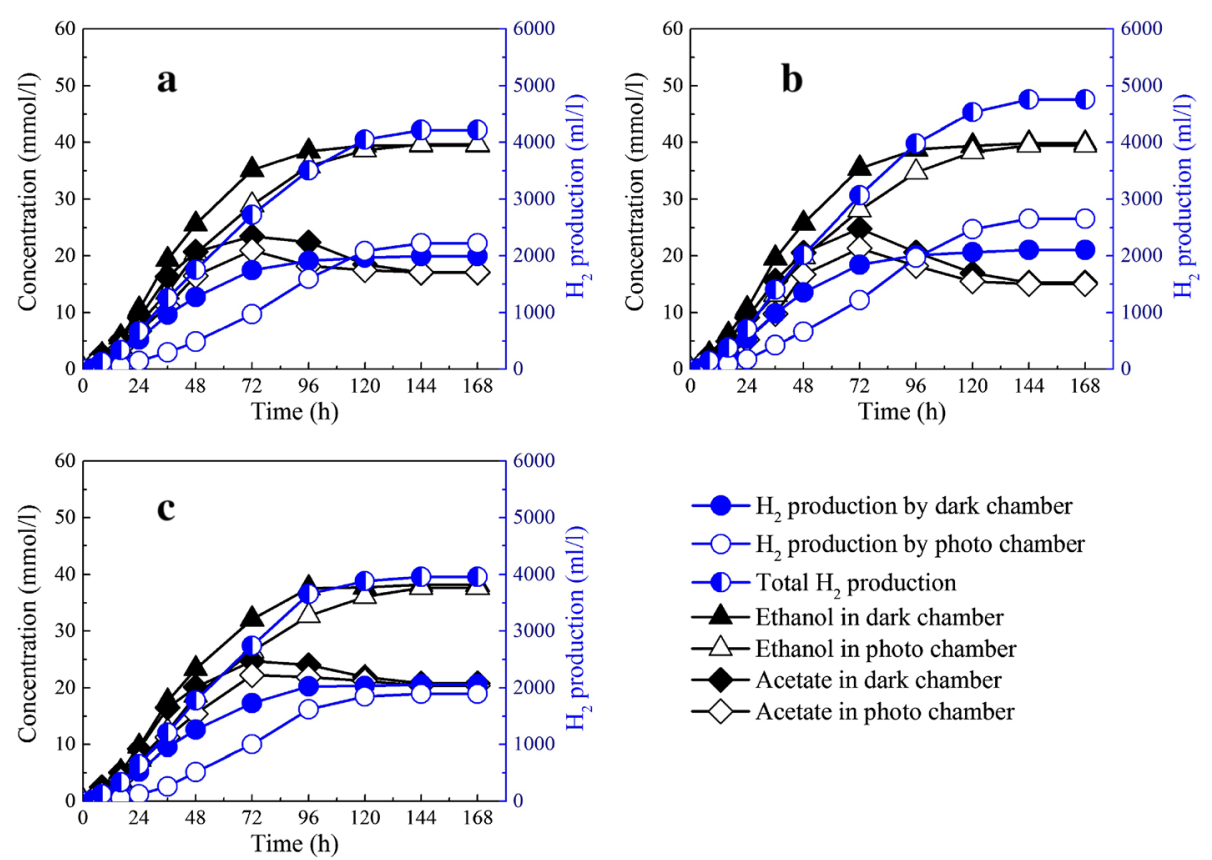

(c), $30 \mathrm{mmol} / \mathrm{L}$ 
that $53.5 \%$ of the environmental impact is generated by the use of phosphate in the fermentation processes [30]. Compared with the co-culture of $E$. harbinense B49 and $R$. faecalis RLD-53 [29], the IDPFR could significantly decrease the usage of phosphate and therefore reduce the environmental impact.

\section{Effect of glucose concentration on $\mathrm{H}_{2}$ production by IDPFR} In the coupled system, glucose concentration not only directly affects cell growth and hydrogen production of $\mathrm{DFB}$, but also influences $\mathrm{pH}$ stability through intermediate products (such as acetate and butyrate) accumulation, which is crucial for hydrogen production and cell growth of PFB. Hydrogen production by the IDPFR was investigated at different glucose concentrations $(4,8$, and $12 \mathrm{~g} / \mathrm{L}$ ). In this test, the working volume ratio of dark to photo chamber was $1: 4$, and the phosphate concentration was $20 \mathrm{mmol} / \mathrm{L}$.

As shown in Figure 4, at glucose concentration of $4 \mathrm{~g} / \mathrm{L}$, the hydrogen production by the dark and photo chambers was $690.05 \mathrm{ml} / \mathrm{L}$ and $865.07 \mathrm{ml} / \mathrm{L}$, respectively. However, glucose was exhausted at $48 \mathrm{~h}$. Also, the maximum acetate accumulation was $9.93 \mathrm{mmol} / \mathrm{L}$, which was used up at
$120 \mathrm{~h}$. At the low substrate concentration, most of the substrate was used for cell growth and to maintain cellular activities rather than for hydrogen production. With an increase of glucose concentration from 4 to $8 \mathrm{~g} / \mathrm{L}$, hydrogen production by the dark chamber was $1,916.92 \mathrm{ml} / \mathrm{L}$, and hydrogen production by the photo chamber was $2,426 \mathrm{ml} /$ L. As a result, the total hydrogen production reached $4,342.92 \mathrm{ml} / \mathrm{L}$ with a hydrogen yield $4.36 \mathrm{~mol} \mathrm{H}_{2} / \mathrm{mol}_{\text {glu- }}$ cose. However, with a further increase of glucose concentration to $12 \mathrm{~g} / \mathrm{L}$, hydrogen production by the dark chamber was further increased to $2,760.68 \mathrm{ml} / \mathrm{L}$, but acetate rapidly accumulated in the IDPFR and the maximum concentration reached $41.13 \mathrm{mmol} / \mathrm{L}$, due to the high glucose concentration. Excessive accumulation of acetate resulted in a rapid drop of $\mathrm{pH}$, so hydrogen production of $R$. faecalis RLD-53 was severely inhibited and decreased sharply to $1,842.30 \mathrm{ml} / \mathrm{L}$. In the co-culture of E. harbinense B49 and immobilized $R$. faecalis RLD-53, hydrogen production reached a maximum at a glucose concentration of $6 \mathrm{~g} / \mathrm{L}$ [29], while the optimum glucose concentration was $8 \mathrm{~g} / \mathrm{L}$ in the IDPFR. Therefore, the IDPFR could be operated with a low hydraulic retention time and high organic loading rate.

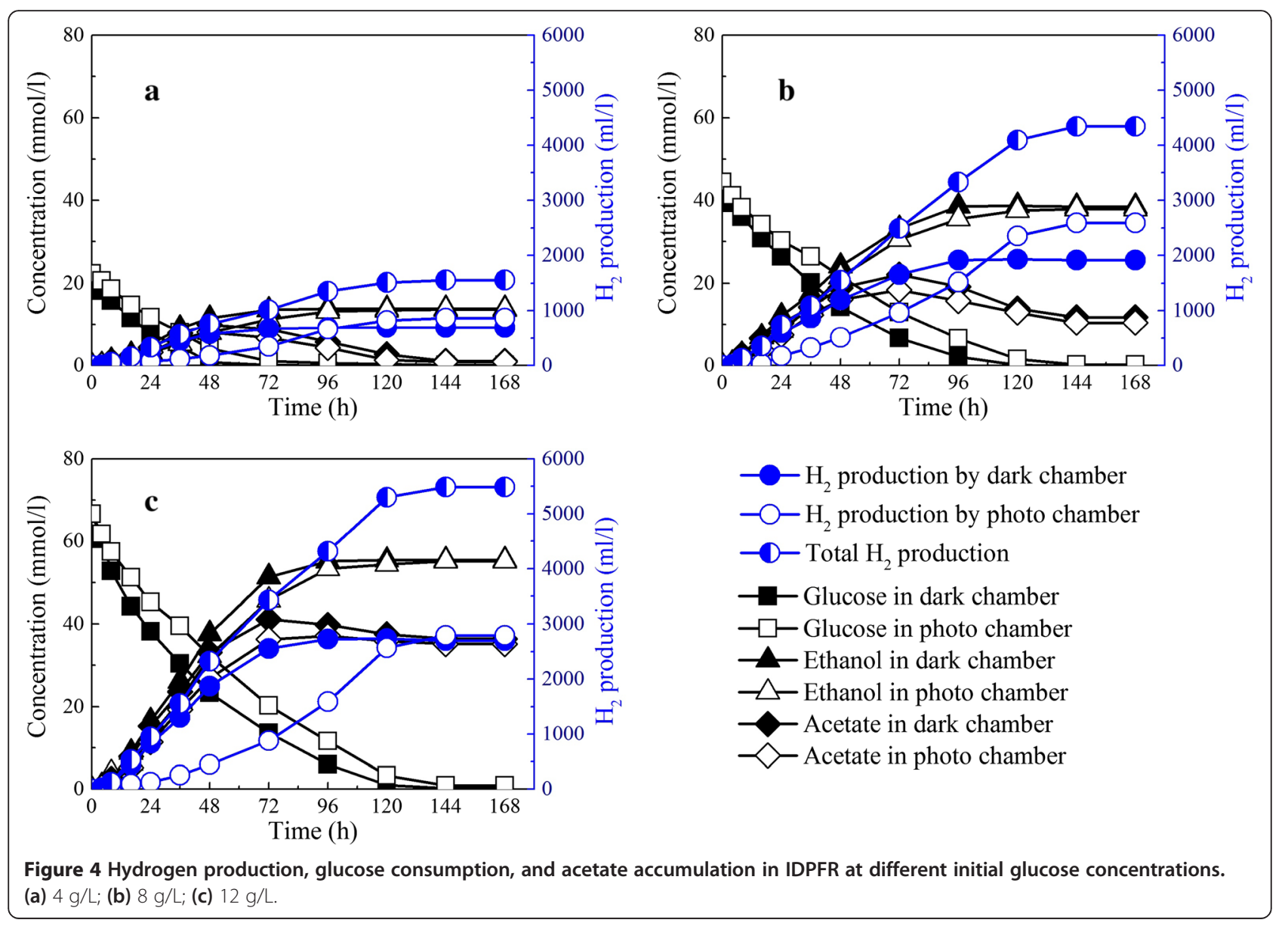




\section{Effect of bacteria inoculation ratio on $\mathrm{H}_{2}$ production by IDPFR}

There are significant kinetic differences in cell growth and metabolic rate between dark and photo-fermentative bacteria, so the inoculation ratio of DFB to PFB may be an effective strategy for stable operation of the IDPFR. The inoculation of the dark chamber was a constant value of $1.6 \mathrm{mg}$ E. harbinense $\mathrm{B} 49$, while the inoculation of the photo chamber was 16,32 , and $48 \mathrm{mg}$, corresponding to inoculation ratios of dark to photo chamber of 1:10, 1:20, and 1:30. In this test, the working volume ratio of dark to photo chamber was 1:4, the phosphate concentration was $20 \mathrm{mmol} / \mathrm{L}$, and the glucose concentration was $8 \mathrm{~g} / \mathrm{L}$.

Hydrogen production by the dark and photo chambers increased with the inoculation ratio and reached a maximum $4.96 \mathrm{~mol}_{2} / \mathrm{mol}$ glucose at an inoculation ratio of 1:20 (Figure 5). At an inoculation ratio of $1: 20$, hydrogen production by the dark chamber was $1,818.85 \mathrm{ml} / \mathrm{L}$, while hydrogen production by the photo chamber was $3,124.22 \mathrm{ml} / \mathrm{L}$, accounting for around $60 \%$ of the total hydrogen production. However, hydrogen production by the photo chamber decreased significantly to
$2,786.30 \mathrm{ml} / \mathrm{L}$ at an inoculation ratio of $1: 30$, because excessive inoculation caused cells to grow quickly with less nutrition for product metabolism [31].

At an inoculation ratio of $1: 20$, acetate produced by $E$. harbinense B49 was effectively used by $R$. faecalis RLD53 without excessive accumulation, so a stable match between E. harbinense B49 and R. faecalis RLD-53 was achieved and acetate was used up. Consequently, ethanol produced by $E$. harbinense B49 was the sole end product in the liquid phase with a concentration of $36.54 \mathrm{mmol} / \mathrm{L}$, corresponding to an ethanol yield of $0.82 \mathrm{~mol}$ ethanol $/ \mathrm{mol}$ glucose. According to stoichiometry, $6 \mathrm{~mol} \mathrm{H}_{2}$ and $1 \mathrm{~mol}$ ethanol could be produced per mol glucose consumed in the IDPFR, so the hydrogen and ethanol production efficiencies achieved $82.67 \%$ and $82.19 \%$, respectively.

\section{Conclusions}

In this work, an integrated dark and photo-fermentative bioreactor (IDPFR) was developed based on the kinetics of dark and photo-fermentative bacteria for complete energy recovery from organic waste. In the IDPFR, the dark and photo-fermentative bacteria were separated by a membrane into dark and photo chambers, while the
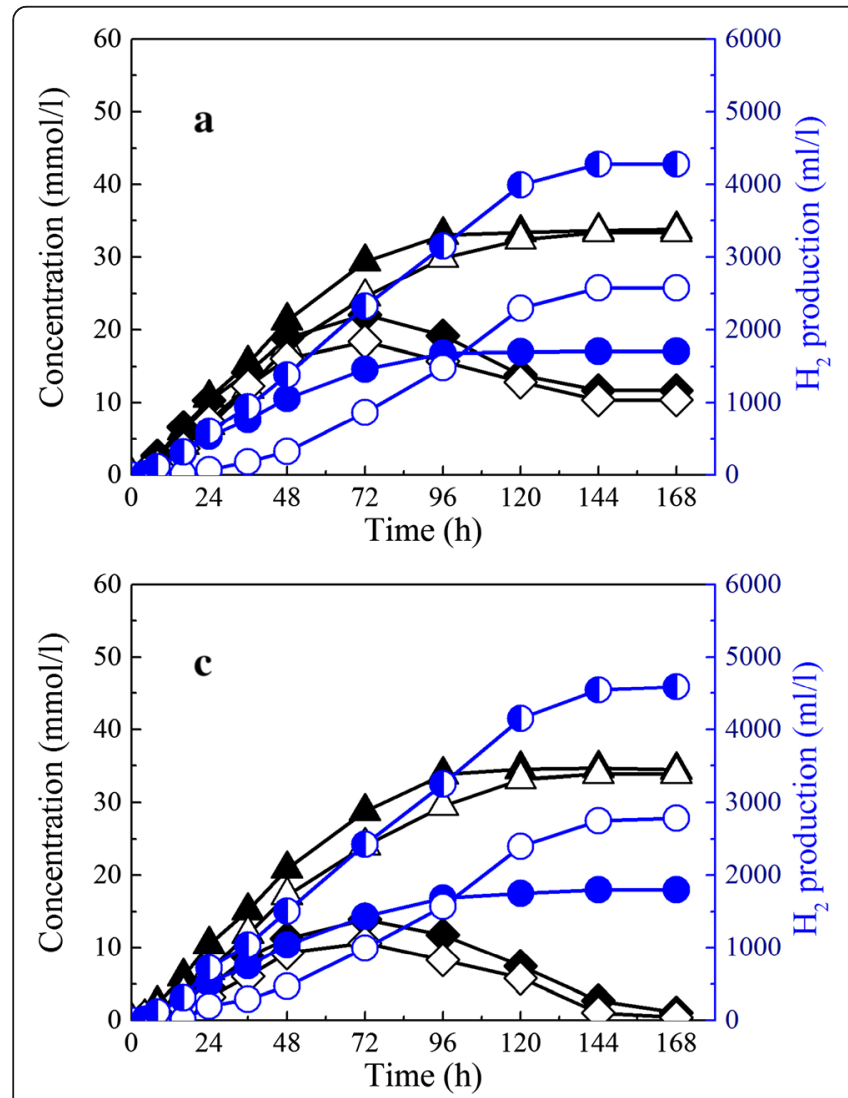
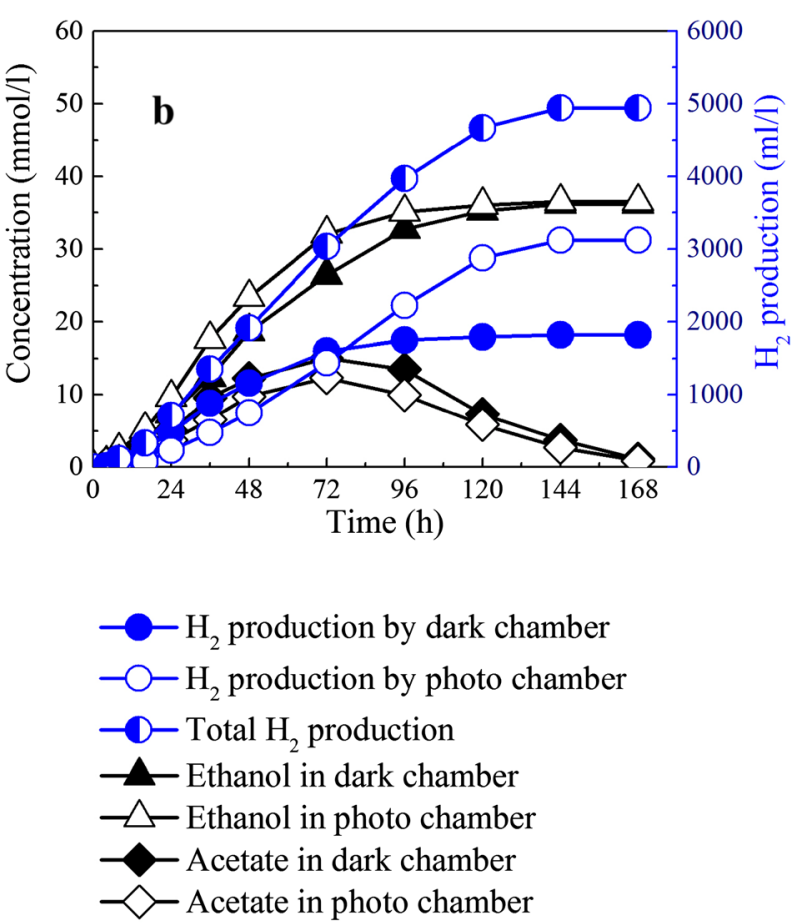

Figure 5 Hydrogen production and acetate accumulation in IDPFR at different inoculation ratios of $E$. harbinese B49 to $R$. faecalis RLD-53. (a) 1:10; (b) 1:20; (c) 1:30. 
organic acids produced by the DFB in the dark chamber freely passed through the membrane into the photo chamber, serving as a carbon source for photofermentation. Increasing the working volume of the photo chamber enabled more $R$. faecalis RLD-53 to cooperate with $E$. harbinense $\mathrm{B} 49$, and the maximum hydrogen yield reached $3.38 \mathrm{~mol} \mathrm{H}_{2} / \mathrm{mol}$ glucose at a working volume ratio of dark chamber to photo chamber of 1:4. Control of the proper phosphate buffer concentration $(20 \mathrm{mmol} / \mathrm{L})$ not only enhanced hydrogen production by maintaining a stable $\mathrm{pH}$ of the IDPFR, but also decreased the environmental impact caused by phosphate in the fermentation process. The maximum hydrogen production (4.96 $\mathrm{mol} \mathrm{H}_{2} / \mathrm{mol}$ glucose) plus ethanol production ( $0.82 \mathrm{~mol} \mathrm{H}_{2} / \mathrm{mol}$ glucose) were obtained by the IDPFR at a phosphate buffer concentration of $20 \mathrm{mmol} / \mathrm{L}$, a glucose concentration of $8 \mathrm{~g} / \mathrm{L}$, and a ratio of dark-photo bacteria of 1:20. This novel reactor not only bypasses complex pretreatments on the effluent in the two-stage process, but also overcomes the imbalance of growth and metabolic rate between DFB and PFB in the co-culture process. Therefore, the IDPFR offers great advantages for enhancing production yield and scale-up application in bioenergy recovery from waste biomass.

\section{Material and methods}

\section{Bacteria and media}

Ethanoligenens harbinese B49, a typical strain used for ethanol-type fermentation, was used as the darkfermentative bacterium. It was isolated from anaerobic activated sludge in a continuous stirred-tank reactor with ethanol-type fermentation [26]. Rhodopseudomonas faecalis RLD-53 was used as the photo-fermentative bacterium; it was isolated previously from freshwater pond sludge and was known to have an excellent ability for hydrogen production [27]. Acetic acid, one of the major metabolites from $E$. harbinese B49, could be further converted into hydrogen by $R$. faecalis RLD-53. The media for E. harbinese B49 and $R$. faecalis RLD-53 were the same as reported earlier in [26] and [27], respectively.

The medium for hydrogen production by coupling $E$. harbinese $\mathrm{B} 49$ and $R$. faecalis RLD-53 consisted of (in $\mathrm{g} / \mathrm{L}$ ) glucose, 10; sodium glutamate, 1.0; yeast extract, 2; $\mathrm{KH}_{2} \mathrm{PO}_{4}$, 1.36; $\mathrm{K}_{2} \mathrm{HPO}_{4}, 1.74 ; \mathrm{MgCl}_{2} .6 \mathrm{H}_{2} \mathrm{O}, 0.2 ; \mathrm{CaCl}_{2}, 0.1$; FeS$\mathrm{O}_{4} .7 \mathrm{H}_{2} \mathrm{O}, 0.012 ; \mathrm{NaCl}, 0.1 ;$ EDTA- $\mathrm{Na}_{2}, 0.1$; L-cysteine, 1 ; trace element solution, $1 \mathrm{ml}$; vitamin solution, $1 \mathrm{ml}$. The $\mathrm{pH}$ of the medium was adjusted to $7.0 \pm 0.2$ by using $\mathrm{HCl}$ or $\mathrm{NaOH}$ solutions.

\section{Kinetic characterizations of dark and photo-fermentative bacteria}

The cell growth kinetics of $E$. harbinese $\mathrm{B} 49$ and $R$. faecalis RLD-53 were determined by a logistic model (Eq. 1), which has been widely used to interpret growth characteristics of hydrogen-producing bacteria [23,32]:

$$
x=\frac{X_{\max }}{1+\left(\frac{X_{\max }}{X_{0}}-1\right) e^{-k_{c} t}}
$$

where $x$ is the cell concentration $(\mathrm{g} / \mathrm{L}) ; X_{O}$ is the initial cell concentration $(\mathrm{g} / \mathrm{L}) ; k_{c}$ is the apparent specific growth rate $\left(\mathrm{h}^{-1}\right)$; and $X_{\max }$ is the maximum cell concentration $(\mathrm{g} / \mathrm{L})$.

The hydrogen production kinetics was examined by a modified Gompertz equation, which has been widely accepted and used to describe the cumulative hydrogen production progress [33,34]:

$$
H=H_{\max } \exp \left\{-\exp \left[\frac{R_{H_{2}} e}{H_{\max }}\left(\lambda_{H_{2}}-t\right)+1\right]\right\}
$$

where $t$ denotes culture time (h); $H$ denotes cumulative hydrogen production ( $\mathrm{ml} \mathrm{H}_{2} / \mathrm{L}$ medium); $H_{\text {max }}$ denotes maximum cumulative hydrogen production $\left(\mathrm{ml} \mathrm{H}_{2} / \mathrm{L}\right.$ medium); e $=2.71828 ; R_{H_{2}}$ denotes maximum $\mathrm{H}_{2}$ production rate $(\mathrm{ml} / \mathrm{L} / \mathrm{h})$; and $\lambda_{H_{2}}$ denotes the lag-phase time (h) for hydrogen production.

In order to make the kinetics of production and degradation of acetic acid comparable, the modified Richards model was used to describe the product formation and substrate degradation simultaneously. To describe the product formation, the Richards function was [35]:

$$
P=K_{p}\left\{1+(m-1) e^{m} \exp \left[\frac{R_{p H A c}}{K_{p}} m^{m /(m-1)}\left(\lambda_{p H A c}-t\right)\right]\right\}^{1 /(1-m)}
$$

where $m$ denotes shape parameter; $t$ denotes culture time (h); $P$ denotes cumulative product concentration $(\mathrm{mmol} / \mathrm{L}$ medium); $K_{p}$ denotes the product formation potential (mmol/L medium); $R_{H A c}$ denotes maximum acetate formation rate $(\mathrm{mmol} / \mathrm{L} / \mathrm{h})$; and $\lambda_{p H A c}$ denotes the lag-phase time (h) for production of acetic acid.

To describe the degradation of a substrate, the Richards function can be rewritten as [36]:

$S=S_{0}\left\{1-\left\{1+(m-1) e^{m} \exp \left[\frac{R_{d H A c}}{S_{0}} m^{m /(m-1)}\left(\lambda_{d H A c}-t\right)\right]\right\}^{1 /(1-m)}\right\}$

where $m$ denotes shape parameter; $t$ denotes culture time (h); $S$ denotes substrate concentration $(\mathrm{mmol} / \mathrm{L}$ medium); $S_{0}$ denotes the initial substrate concentration (mmol/L medium); $R_{d H A c}$ denotes maximum acetate consumption rate $(\mathrm{mmol} / \mathrm{L} / \mathrm{h})$; and $\lambda_{d H A c}$ denotes the lag-phase time (h) for degradation of acetic acid. 


\section{Integrated dark and photo-fermentative bioreactor setup and operation}

A schematic of the integrated dark and photo-fermentative bioreactor setup is depicted in Figure 6. The reactor was divided into dark and photo chambers by a cellulose acetate membrane with a diameter of $6 \mathrm{~cm}$ (pore size $0.22 \mu \mathrm{m}$, thickness $100 \mu \mathrm{m}$, Shanghai, China), which permitted the substrate to pass freely through while excluding bacterial cells. Consequently, the dark and photo-fermentative bacteria were separated into dark and photo chambers.

The illuminated area-to-working volume (A/V) ratio has a significant influence on the performance of a photobioreactor [37]. To avoid confusion between the effect of the $\mathrm{A} / \mathrm{V}$ ratio and the working volume ratio of the dark and photo chambers, the IDPFR was designed to keep a constant $\mathrm{A} / \mathrm{V}$ ratio when increasing the volume of the reactor. The reactor wall thickness was $10 \mathrm{~mm}$. The dark chamber had the following internal dimensions: length of $30 \mathrm{~mm}\left(L_{d}=30 \mathrm{~mm}\right)$, width of $50 \mathrm{~mm}\left(W_{d}=50 \mathrm{~mm}\right)$, and height of $50 \mathrm{~mm}\left(H_{d}=\right.$ $50 \mathrm{~mm}$ ). The photo chamber was designed with the same width and height as the dark chamber, while the length of the photo chamber $\left(L_{p}\right)$ was $60,90,120$, and $150 \mathrm{~mm}$, corresponding to the working volume ratio at $1: 2,1: 3,1: 4$, and 1:5. As the light penetrated the reactor through the top surface of the photo chamber, the surface area receiving light energy increased with the increasing volume, reaching $30,45,60$, and $75 \mathrm{~cm}^{2}$, respectively. As a result, the $\mathrm{A} / \mathrm{V}$ ratio was kept constant at $37.5 \mathrm{~m}^{2} / \mathrm{m}^{3}$.

The IDPFRs were chemically sterilized with hydrogen peroxide $(3 \% \mathrm{v} / \mathrm{v})$ solution and thoroughly rinsed with distilled water. At startup, the dark and photo chambers were filled with different volumes of hydrogen production medium, and then flushed with argon gas for
10 min to maintain anaerobic conditions. E. harbinese B49 and R. faecalis RLD-53 in the mid-exponential growth phase were centrifuged and washed with a phosphate buffer solution, and inoculated into the dark and photo chambers, respectively. The liquid in the reactor was homogeneously mixed using a magnetic stirrer at $80 \mathrm{rpm}$ at a constant temperature of $35 \pm 1^{\circ} \mathrm{C}$. The light intensity on the outside surface of the photo chambers of the reactors was maintained at $150 \mathrm{~W} / \mathrm{m}^{2}$ by incandescent lamps $(60 \mathrm{~W})$.

\section{Analytical methods}

Biogas was sampled from the head space of the dark and photo chambers of the reactor with gas-tight glass syringes, and the hydrogen content was determined by using a gas chromatograph (Agilent 4890D, Agilent Technologies, Santa Clara, CA, USA). The gas chromatograph column was Alltech Molesieve 5A 80/100. Argon was used as the carrier gas with a flow rate of $30 \mathrm{ml} / \mathrm{min}$. The temperatures of the oven, injection, detector, and filament were $35,120,120$, and $140^{\circ} \mathrm{C}$, respectively. The glucose concentration in the culture broth was determined with a Glucose HK kit (Sigma). Volatile fatty acids and ethanol in the supernatant of the culture broth were determined using a second gas chromatograph (Agilent 7890 A, Agilent Technologies, USA) equipped with a flame ionization detector. The liquor samples were first centrifuged at 12,000 rpm for $5 \mathrm{~min}$ and then filtered through a $0.22-\mu \mathrm{m}$ membrane before the free acids were analyzed. The operational temperatures of the injection port, the column, and the detector were 220,190 , and $220^{\circ} \mathrm{C}$, respectively. Nitrogen was used as the carrier gas at a flow rate of $50 \mathrm{ml} / \mathrm{min}$.

The light intensity was measured at the surface of the reactor with a TENMARS TM-207 Solar Power Meter

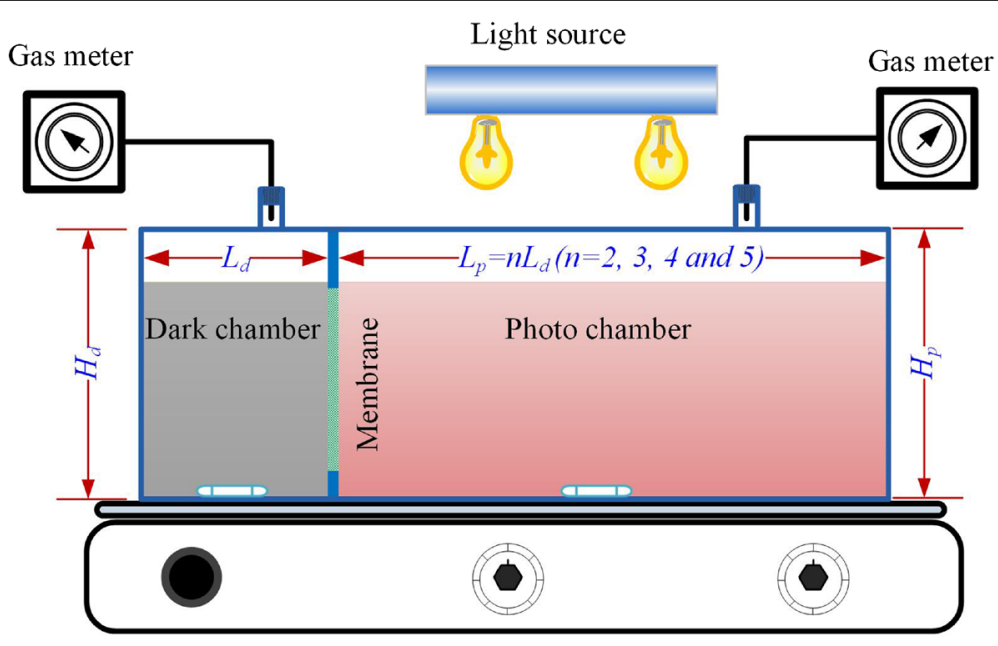

Heating magnetic stirrer

Figure 6 Schematic diagram of integrated dark and photo-fermentative bioreactor. 
(Tenmars Electronics Co., Ltd., Taiwan, China). The cell biomass was determined by filtering the culture broth through a cellulose acetate membrane filter $(0.22-\mu \mathrm{m}$ pore size, $50 \mathrm{~mm}$ in diameter). The filter was then rinsed with deionized water to remove salts or non-cellular materials. Each loaded filter was dried at $105^{\circ} \mathrm{C}$ until the weight became consistent. The dry weight of a blank filter was subtracted from that of the loaded filter to obtain the cell biomass.

\begin{abstract}
Abbreviations
$\lambda_{\text {dHAc }}$ : lag-phase time for degradation of acetic acid (h); $\lambda_{H_{2}}$ : lag-phase time for hydrogen production (h); $\lambda_{\text {PHAc }}$ : lag-phase time for production of acetic acid (h); DFB: dark-fermentative bacteria; e: the base of the natural logarithm; $\mathrm{H}$ : cumulative hydrogen production ( $\mathrm{ml} \mathrm{H}_{2} / \mathrm{L}$ medium); $H_{\text {max }}$ maximum cumulative hydrogen production ( $\mathrm{ml} \mathrm{H}_{2} / \mathrm{L}$ medium); IDPFR: integrated dark and photo-fermentative (bio)reactor; $k_{c}$ : apparent specific growth rate $\left(\mathrm{h}^{-1}\right)$; $K_{p}$ : product formation potential ( $\mathrm{mmol} / \mathrm{L}$ medium); $\mathrm{m}$ : shape parameter; $P$ : cumulative product concentration (mmol/L medium); PFB: photo-fermentative bacteria; $R_{d H A c}$ maximum acetate consumption rate $(\mathrm{mmol} / \mathrm{L} / \mathrm{h}) ; R_{\mathrm{H}_{2}}$ : maximum $\mathrm{H}_{2}$ production rate $(\mathrm{ml} / \mathrm{L} / \mathrm{h}) ; R_{p H A c}$ maximum acetate production rate $(\mathrm{mmol} / \mathrm{L} / \mathrm{h})$; $\mathrm{S}$ : substrate concentration (mmol/L medium); $S_{0}$ : initial substrate concentration (mmol/L medium); t: culture time (h); $x$ : cell concentration $(\mathrm{g} / \mathrm{L}) ; X_{0}$ : initial cell concentration (g/L); $X_{\text {max }}$ : maximum cell concentration (g/L).
\end{abstract}

\section{Competing interests}

The authors declare that they have no competing interests.

\section{Authors' contributions}

All authors contributed intellectually via scientific discussions during the work and have read and approved the final manuscript. GJX and BFL designed the study, executed the experimental work, interpreted the data, and drafted the manuscript. DFX and JD commented on the manuscript and contributed to the design of the study. HYR and CM assisted with the analysis and discussed the results. RQW and XZ reviewed and edited the manuscript. NQR contributed to the design of the study and the data interpretation and reviewed the manuscript.

\section{Acknowledgements}

The authors would like to thank the Natural Science Foundation of China (51478139), Fundamental Research Funds for the Central Universities (HIT. BRETIII.201418), Harbin Innovation Talents Funding of Science and Technology (2014RFQXJ084), State Key Laboratory of Urban Water Resource and Environment (Harbin Institute of Technology) (2015TS02) and the Shanghai Tongji Gao Tingyao Environmental Science \& Technology Development Foundation for supporting this study.

Received: 9 September 2014 Accepted: 18 December 2014

Published online: 22 January 2015

\section{References}

1. Cao GL, Zhao L, Wang AJ, Wang ZY, Ren NQ. Single-step bioconversion of lignocellulose to hydrogen using novel moderately thermophilic bacteria. Biotechnol Biofuels. 2014;7:82.

2. Serrano DP, Dufour J, Iribarren D. On the feasibility of producing hydrogen with net carbon fixation by the decomposition of vegetable and microalgal oils. Energy Environ Sci. 2012;5:6126-35.

3. Ewan $B C R$, Allen RWK. A figure of merit assessment of the routes to hydrogen. Int J Hydrogen Energy. 2005;30:809-19.

4. Das D, Veziroğlu TN. Hydrogen production by biological processes: a survey of literature. Int J Hydrogen Energy. 2001;26:13-28.

5. Meher Kotay S, Das D. Biohydrogen as a renewable energy resource - prospects and potentials. Int J Hydrogen Energy. 2008;33:258-63.

6. Ren NQ, Liu BF, Ding J, Guo WQ, Cao GL, Xie GJ. The effect of butyrate concentration on photo-hydrogen production from acetate by Rhodopseudomonas faecalis RLD-53. Int J Hydrogen Energy. 2008:33:5981-5.

7. Xie GJ, Liu BF, Guo WQ, Ding J, Xing DF, Nan J, et al. Feasibility studies on continuous hydrogen production using photo-fermentative sequencing batch reactor. Int J Hydrogen Energy. 2012;37:13689-95.
8. Kim DH, Lee JH, Kang S, Hallenbeck PC, Kim EJ, Lee JK, et al. Enhanced photofermentative $\mathrm{H}_{2}$ production using Rhodobacter sphaeroides by ethanol addition and analysis of soluble microbial products. Biotechnol Biofuels. 2014;7:79.

9. Ren NQ, Chua H, Chan SY, Tsang YF, Wang YJ, Sin N. Assessing optimal fermentation type for bio-hydrogen production in continuous-flow acidogenic reactors. Bioresour Technol. 2007;98:1774-80.

10. Masset J, Calusinska M, Hamilton C, Hiligsmann S, Joris B, Wilmotte A, et al. Fermentative hydrogen production from glucose and starch using pure strains and artificial co-cultures of Clostridium spp. Biotechnol Biofuels. 2012;5:35.

11. Claassen PAM, de Vrije T, Koukios E, van Niel E, Eroglu I, Modigell M, et al. Non-thermal production of pure hydrogen from biomass: HYVOLUTION. J Clean Prod. 2010;18(Supplement 1):S4-8.

12. Ozgür E, Afsar N, de Vrije T, Yücel M, Gündüz U, Claassen PAM, et al. Potential use of thermophilic dark fermentation effluents in photofermentative hydrogen production by Rhodobacter capsulatus. J Clean Prod. 2010;18(Supplement 1):S23-8.

13. Lo YC, Chen CY, Lee CM, Chang JS. Sequential dark-photo fermentation and autotrophic microalgal growth for high-yield and $\mathrm{CO}_{2}$-free biohydrogen production. Int J Hydrogen Energy. 2010;35:10944-53.

14. Liu BF, Ren NQ, Xing DF, Ding J, Zheng GX, Guo WQ, et al. Hydrogen production by immobilized $R$. faecalis RLD-53 using soluble metabolites from ethanol fermentation bacteria E. harbinense B49. Bioresour Technol. 2009:100:2719-23.

15. Liu BF, Ren NQ, Xie GJ, Ding J, Guo WQ, Xing DF. Enhanced bio-hydrogen production by the combination of dark- and photo-fermentation in batch culture. Bioresour Technol. 2010;101:5325-9.

16. Zhao YX, Chen YG. Nano- $\mathrm{TiO}_{2}$ enhanced photofermentative hydrogen produced from the dark fermentation liquid of waste activated sludge. Environ Sci Technol. 2011;45:8589-95.

17. Cheng J, Xia A, Liu Y, Lin R, Zhou J, Cen K. Combination of dark- and photo-fermentation to improve hydrogen production from Arthrospira platensis wet biomass with ammonium removal by zeolite. Int J Hydrogen Energy. 2012;37:13330-7.

18. Castro-Villalobos MC, García-Morales JL, Fernández FJ. By-products inhibition effects on bio-hydrogen production. Int J Hydrogen Energy. 2012;37:7077-83.

19. Lo YC, Chen WM, Hung $\mathrm{CH}$, Chen SD, Chang JS. Dark $\mathrm{H}_{2}$ fermentation from sucrose and xylose using $\mathrm{H}_{2}$-producing indigenous bacteria: feasibility and kinetic studies. Water Res. 2008;42:827-42.

20. Chen WM, Tseng ZJ, Lee KS, Chang JS. Fermentative hydrogen production with Clostridium butyricum CGS5 isolated from anaerobic sewage sludge. Int J Hydrogen Energy. 2005;30:1063-70.

21. Kumar N, Das D. Enhancement of hydrogen production by Enterobacter cloacae IIT-BT 08. Process Biochem. 2000:35:589-93.

22. Boran E, Özgür E, Yücel M, Gündüz U, Eroglu I. Biohydrogen production by Rhodobacter capsulatus in solar tubular photobioreactor on thick juice dark fermenter effluent. J Clean Prod. 2012;31:150-7.

23. Eroğlu I, Tabanoğlu A, Gündüz U, Eroğlu E, Yücel M. Hydrogen production by Rhodobacter sphaeroides O.U.001 in a flat plate solar bioreactor. Int J Hydrogen Energy. 2008;33:531-41.

24. Pott RWM, Howe CJ, Dennis JS. Photofermentation of crude glycerol from biodiesel using Rhodopseudomonas palustris: comparison with organic acids and the identification of inhibitory compounds. Bioresour Technol. 2013;130:725-30.

25. Boran E, Özgür E, Yücel M, Gündüz U, Eroglu I. Biohydrogen production by Rhodobacter capsulatus Hup ${ }^{-}$mutant in pilot solar tubular photobioreactor. Int J Hydrogen Energy. 2012;37:16437-45.

26. Wang XJ, Ren NQ, Sheng Xiang W, Qian GW. Influence of gaseous end-products inhibition and nutrient limitations on the growth and hydrogen production by hydrogen-producing fermentative bacterial B49. Int J Hydrogen Energy. 2007;32:748-54.

27. Ren NQ, Liu BF, Ding J, Xie GJ. Hydrogen production with $R$. faecalis RLD-53 isolated from freshwater pond sludge. Bioresour Technol. 2009;100:484-7.

28. Tang J, Yuan Y, Guo WQ, Ren NQ. Inhibitory effects of acetate and ethanol on biohydrogen production of Ethanoligenens harbinese B49. Int J Hydrogen Energy. 2012;37:741-7.

29. Xie GJ, Feng LB, Ren NQ, Ding J, Liu C, Xing DF, et al. Control strategies for hydrogen production through co-culture of Ethanoligenens harbinense B49 and immobilized Rhodopseudomonas faecalis RLD-53. Int J Hydrogen Energy. 2010;35:1929-35.

30. Ochs D, Wukovits W, Ahrer W. Life cycle inventory analysis of biological hydrogen production by thermophilic and photo fermentation of potato steam peels (PSP). J Clean Prod. 2010;18(Supplement 1):S88-94. 
31. Liu F, Fang B. Optimization of bio-hydrogen production from biodiesel wastes by Klebsiella pneumoniae. Biotechnol J. 2007;2:374-80.

32. Xie GJ, Liu BF, Xing DF, Ding J, Nan J, Ren HY, et al. The kinetic characterization of photofermentative bacterium Rhodopseudomonas faecalis RLD-53 and its application for enhancing continuous hydrogen production. Int J Hydrogen Energy. 2012;37:13718-24.

33. Lin CY, Wu CC, Wu JH, Chang FY. Effect of cultivation temperature on fermentative hydrogen production from xylose by a mixed culture. Biomass Bioenergy. 2008;32:1 109-15.

34. Xie GJ, Liu BF, Xing DF, Nan J, Ding J, Ren NQ. Photo-fermentative bacteria aggregation triggered by L-cysteine during hydrogen production. Biotechnol Biofuels. 2013;6:64.

35. Qi WT, Ma J, Yu WT, Xie YB, Wang W, Ma XJ. Behavior of microbial growth and metabolism in alginate-chitosan-alginate (ACA) microcapsules. Enzyme Microb Technol. 2006;38:697-704

36. Wang YY, Fan YZ, Gu JD. Dimethyl phthalate ester degradation by two planktonic and immobilized bacterial consortia. Int Biodeterior Biodegrad. 2004:53:93-101.

37. Dasgupta CN, Jose Gilbert J, Lindblad P, Heidorn T, Borgvang SA, Skjanes K, et al. Recent trends on the development of photobiological processes and photobioreactors for the improvement of hydrogen production. Int J Hydrogen Energy. 2010;35:10218-38.

\section{Submit your next manuscript to BioMed Central and take full advantage of:}

- Convenient online submission

- Thorough peer review

- No space constraints or color figure charges

- Immediate publication on acceptance

- Inclusion in PubMed, CAS, Scopus and Google Scholar

- Research which is freely available for redistribution 